University of Nebraska - Lincoln

DigitalCommons@University of Nebraska - Lincoln

$9-5-2008$

\title{
Librarian Status at US Research Universities: Extending the Typology
}

Mary K. Bolin

University of Nebraska--Lincoln, mbolin2@unl.edu

Follow this and additional works at: https://digitalcommons.unl.edu/libraryscience

Part of the Library and Information Science Commons

Bolin, Mary K., "Librarian Status at US Research Universities: Extending the Typology" (2008). Faculty Publications, UNL Libraries. 167.

https://digitalcommons.unl.edu/libraryscience/167

This Article is brought to you for free and open access by the Libraries at University of Nebraska-Lincoln at DigitalCommons@University of Nebraska - Lincoln. It has been accepted for inclusion in Faculty Publications, UNL Libraries by an authorized administrator of DigitalCommons@University of Nebraska - Lincoln. 
Provided for non-commercial research and education use. Not for reproduction, distribution or commercial use.

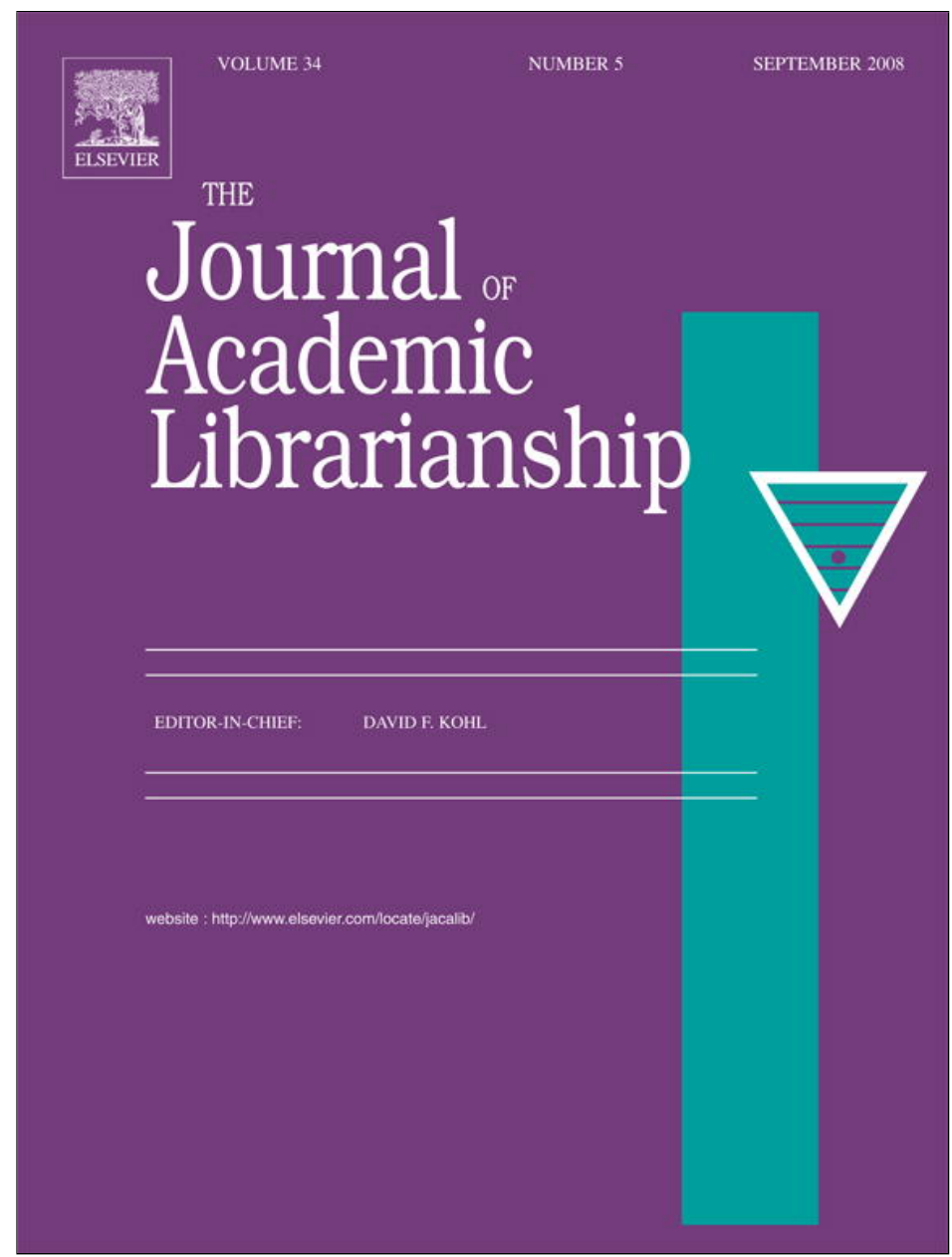

This article appeared in a journal published by Elsevier. The attached copy is furnished to the author for internal non-commercial research and education use, including for instruction at the authors institution and sharing with colleagues.

Other uses, including reproduction and distribution, or selling or licensing copies, or posting to personal, institutional or third party websites are prohibited.

In most cases authors are permitted to post their version of the article (e.g. in Word or Tex form) to their personal website or institutional repository. Authors requiring further information regarding Elsevier's archiving and manuscript policies are encouraged to visit:

http://www.elsevier.com/copyright 


\title{
Librarian Status at US Research Universities: Extending the Typology
}

\author{
by Mary K. Bolin
}

Available online 8 August 2008

\begin{abstract}
A typology of librarian status developed for land grant universities is extended to US research universities. Land grant librarians are tenure-track faculty in $70 \%$ of institutions. Librarians in the expanded population have that status slightly more than half the time. Institution size, geographic region, and public/private governance are discussed.
\end{abstract}

Mary K. Bolin is Professor and Chair, Technical Services, University Libraries, University of Nebraska-Lincoln, Lincoln, NE 68588-4100, USA <mbolin2@unl.edu>.

\section{INTRODUCTION}

The organizational role and status of academic librarians in the US remains a topic of interest. It can be a controversial and fiercely argued topic. The arguments for and against faculty status reflect the continuing search and struggle for recognition of knowledge and expertise and for a collaborative and collegial role in institutional programs. Faculty status for librarians has the support of the American Library Association (ALA) and its academic division, the Association of College and Research Libraries (ACRL). Since ALA and the American Association of University Professors (AAUP) issued the "Joint Statement" on faculty status in 1971, the implementation of faculty status among librarians has been widespread but not uniform. Determining whether librarians at a particular institution, or among a population of institutions, are faculty or staff requires asking more than a yes/no question. Features such as rank, tenure, and so on, are crucial in determining the nature of librarian status at a particular institution, and understanding the differences in implementation of that status in different institutions. ACRL has issued a number of statements and guidelines that define faculty status. ${ }^{2-4}$ The "ACRL Standards for Faculty Status for College and University Librarians", describe nine conditions that should be part of librarian faculty status. These include peer review for promotion, eligibility for tenure, access to sabbatical leaves and research funds, and representation in governance, among other things. Those standards acknowledge implicitly that the particulars of faculty status are as important as the status itself.

\section{Purpose of the Study}

This study is a description and categorization of librarian status at American research universities $(n=119)$. The population includes all US universities whose library is a member of the Association of Research Libraries (ARL), an organization of 123 libraries in the US and Canada. In addition to that group of ARL libraries, the population includes any land grant universities who are not also ARL members of, and any "flagship" state universities who are neither ARLs nor land grants, e.g., the University of Montana. ${ }^{6}$ All institutions in the population are classified as "Research-Very High" or "Research-High" in the Carnegie Classification of Institutions of Higher Education. ${ }^{7}$

University websites are the source of data on the status of librarians, including rank system, tenure status, and representation in faculty governance. The typology of librarian status created by the author for land grant universities ${ }^{8}$ is extended to a larger 
population. This approach looks beyond binary categorizations (faculty/staff) by examining particular characteristics of the implementation of models of status. At the same time, it also attempts to move beyond the atomization that is sometimes the result of describing characteristics in isolation from each other, e.g., looking at tenure, representation in governance, etc., without considering how those characteristics relate to each other or co-occur.

\section{"The question of whether a university employee is faculty or staff, and what it means to be in one of those categories, can be viewed through the lens of semantic prototypes..."}

The creation of the typology is informed by linguistic analysis. Typology is a concept that is also used in linguistics. Scholars such as Bernard Comrie, ${ }^{9}$ William Croft, ${ }^{10}$ and Joseph Greenberg $^{11}$ have attempted to compare the features (phonological, syntactic, and semantic) of the world's languages, define universal types, and assess their frequency and the ways that types cluster or are correlated. The approach to typology used in this project is similar. The creation of the typology is also informed by the approach to categorization used by prototype semantics. The question of whether a university employee is faculty or staff, and what it means to be in one of those categories, can be viewed through the lens of semantic prototypes and approaches to categorization, which have been discussed by Eleanor Rosch, ${ }^{12}$ George Lakoff, and George Lakoff and Mark Johnson, ${ }^{13}$ among others, and which explore the ways that humans cognitively conceive and represent categories. Work by linguists on categorization includes intercultural studies of color terms, kinship terms, and folk taxonomies of plants and animals. Prototype theory views categories as having central and peripheral members. While speakers may not agree on where the boundaries of a category are, there is agreement on where the middle of the category is, or what the best representative of the category is, e.g., a robin or a sparrow is a better example of the English category "bird" than a penguin or turkey. Prototype theory is very relevant to the question of what it means to be a faculty member. If the prototypical example of a bird is a robin, but a penguin is still a bird, then functional wings, flight, size, feathers, beak, egg-laying, and habitat may be among the characteristics considered in determining "birdness," but it is not necessary to have all the characteristics in order to belong to the category. In the case of faculty, an English professor or chemistry professor may be considered prototypical. The characteristics that give them centrality in the category are teaching, being members of a teaching department and college that generate credit hours, the $\mathrm{PhD}$ as a terminal degree, pursuing research and scholarship, and being part of the "academic side" of the organization. Librarians have made the case based on a number of these characteristics. On the other hand, deciding whether a penguin is a bird is not the same as deciding whether a librarian is a faculty member, because it leaves out the political struggle that is part of university governance. Librarians are faculty because there is a certain semantic logic, but also because they have worked on winning that status for themselves, because it may help universities add to the numbers of women faculty and tenured women, and so on. Organizations can change categories, redefine them, and invent new ones. Nevertheless, librarians could never have achieved faculty status if there were not some cognitive, cultural, and social semantic basis for accepting them in that category.

\section{Literature ReVIEW}

The author's study of librarian status at land grant universities includes a review of the literature of faculty status, including the history of librarian faculty status, surveys, and arguments for and against faculty status. ${ }^{14}$ Literature that deals specifically with research libraries includes a number of studies by ARL on librarian status, such as the study by Tracy Bicknell-Holmes and Kay Logan-Peters of external review for promotion and tenure, ${ }^{15}$ Susan A. Massey and Mary Ann Sheble's survey of library faculty organizations, ${ }^{16}$ and Jack Siggins, and Ronald Naylor's look at academic status for librarians. ${ }^{17}$

Surveys of librarian status include those done by Virgil F. Massman, ${ }^{18}$ W. Bede Mitchell, ${ }^{19}$ and W. Bede Mitchell and Mary Reichel. ${ }^{20}$ Shannon Cary ${ }^{21}$ describes an ACRL study of librarian status and participation in governance. ${ }^{22}$ Janet Krompart and Clara DiFelice ${ }^{23}$ did a meta-analysis of 36 faculty status surveys done in the 1970s and 1980s.

Work by linguists on categorization includes intercultural studies of color terms, kinship terms, and folk taxonomies of plants and animals. Approaches to categorization include prototype theory. Lakoff ${ }^{24}$ discusses a number of aspects of prototype theory, including:

- Family resemblances: "The idea that members of a category may be related to one another without all members having any properties in common that define the category."

- Centrality: "The idea that some members of a category may be "better examples" of that category than others."

- Generativity: "Categories that are defined by a generator (a particular member or sub-category) plus rules (or a general principle such as similarity). In some cases, the generator has the status of a central, or 'prototypical' category member."

- Membership gradience: "The idea that at least some categories have degrees of membership and no clear boundaries."

- Centrality gradience: "The idea that members (or subcategories) which are clearly within the category boundaries may still be more or less central."

\section{Methodology, Research Design, and Data Analysis}

There are numerous surveys of academic librarian status. The present survey includes data on institutional characteristics and characteristics of librarian status with the goal of creating a meaningful context for interpreting the results. The data gathered includes salient characteristics such as institutional governance (private or public), size, and geography, and salient features of status, including rank systems, administrator title, and tenure status. The typology of status creates a continuum or matrix rather than a binary condition (faculty/staff). Some very salient elements, such as tenure, are given more weight in the creation of the typology. 
The methodology is a census of all institutions in the population. Data was found on institutional websites. The number of possible values for each data element was not predetermined.

\section{Institutional Characteristics}

- ARL status ${ }^{25}$ and rank ${ }^{26}$

- Land grant status ${ }^{27}$

- Census region of the university (one of four US geographic regions devised by the US Census Bureau) ${ }^{28}$

- University size (based on ARL rank)

- Public or private institutional governance

\section{Librarian Status Characteristics}

- University employee group (faculty or staff)

- Title of library administrator (dean, director, etc.)

- Rank system

O Professorial ranks (Assistant Professor, Associate Professor, Professor)

○ Parallel ranks (Assistant Librarian, Associate Librarian, Librarian)

O Librarian ranks (Librarian I, II, III, IV)

O Other

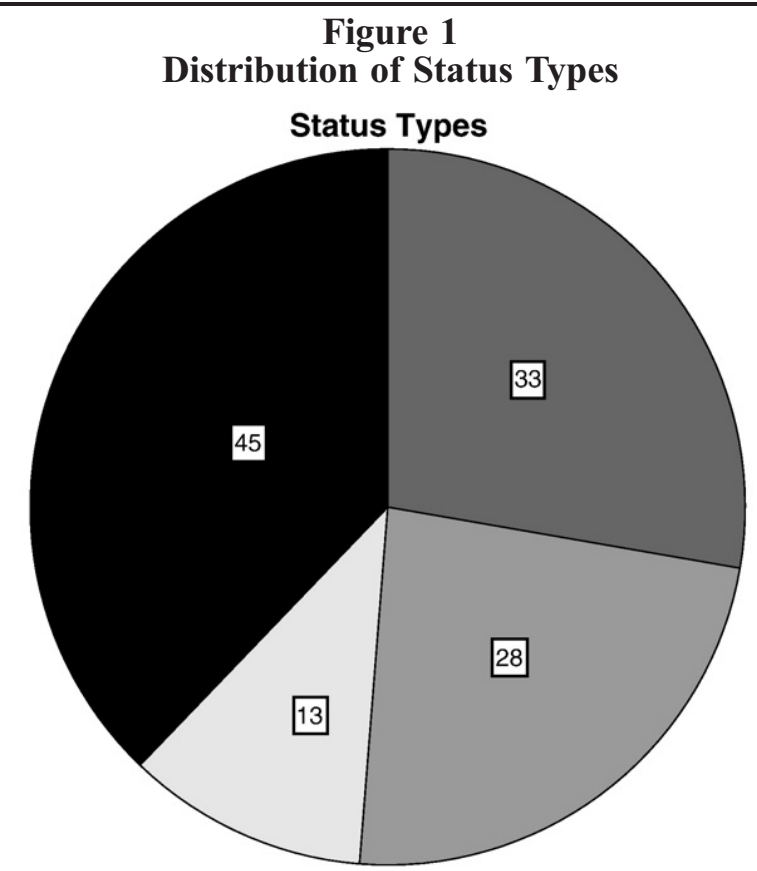

$\square$ 1: Professorial

$\square$ 3: Other ranks without tenure

$\square$ 2: Other ranks with tenure
4: Non-faculty (Staff)
Table 1

Distribution of Status Types

\begin{tabular}{lcc}
\hline \multicolumn{1}{c}{ Type } & Frequency & Percent \\
\hline 1: Professorial & 33 & 27.7 \\
2: Other ranks with tenure & 28 & 23.5 \\
3: Other ranks without tenure & 13 & 10.9 \\
4: Non-faculty (staff) & 45 & 37.8 \\
Total & 119 & 100.0 \\
\hline
\end{tabular}

- Tenure eligibility

- Representation on faculty senate

A summary of the typology data is found in Appendix A. The information was found in one or more places on the institutional website, including promotion and tenure documents, faculty handbooks, policy manuals, and so on. The data were compiled in a spreadsheet and imported into SPSS, which was used to create frequencies and cross tabulations. The typology is based on employee group, rank system, and tenure status.

\section{Librarian Status Typology}

There are three status types in which librarians are faculty, and one in which they are staff. Types:

1. Faculty: Professorial ranks

2. Faculty: Other ranks with tenure

3. Faculty: Other ranks without tenure

4. Non-faculty: Professional or academic staff

The typology was first developed based on data about land grant universities only. The rationale for the typology begins with the idea that professorial rank represents the universal teaching faculty model and is one necessary category. Academic or professional staff status is also a necessary category, since it represents a model in which librarians are not faculty. Between those two end points are "other ranks" (parallel ranks, e.g., Assistant Librarian, and librarian ranks, e.g., Librarian I) with tenure and other ranks without tenure. Tenure is a salient aspect of faculty status, and it plays an important role in creating a typology of status.

Type 1 and Type 2 are generally readily identified, because librarians who are tenure-track faculty are clearly identified in university documentation. Types 3 and 4, on the other hand, can be harder to distinguish, because some institutions have given librarians a status that parallels or has some features of faculty status.

\section{RESULTS}

The distribution of types among US research universities (see Fig. 1 and Table 1):

1. Faculty: Professorial ranks (33)

2. Faculty: Other ranks with tenure (28) 
Table 2

Librarian Status Type Distribution

\begin{tabular}{lcc}
\hline \multicolumn{1}{c}{ Land grant } & Frequency & Percent \\
\hline 1: Professorial & 21 & 42 \\
2: Other ranks with tenure & 14 & 28 \\
3: Other ranks without tenure & 5 & 10 \\
4: Non-faculty (staff) & 10 & 20 \\
Total & 50 & 100
\end{tabular}

ARL

1: Professorial $20 \quad 20.6$

2: Other ranks with tenure

3: Other ranks without tenure

4: Non-faculty (staff)

43.4

Total

\section{Public institutions}

1: Professorial

2: Other ranks with tenure

3: Other ranks without tenure

4: Non-faculty (staff)

Total

\section{Private institutions}

1: Professorial

2: Other ranks with tenure

3: Other ranks without tenure

\section{Faculty: Other ranks without tenure (13)}

4. Non-faculty: Professional or academic staff (45)

Among US research universities, librarians are faculty in approximately $62 \%$ of institutions, with tenure-track faculty representing slightly more than half the population. Looking at the distribution of status types in various segments of the population further illuminates this finding (Table 2).

\footnotetext{
"Among US research universities, librarians are faculty in approximately $62 \%$ of institutions, with tenure-track faculty representing slightly more than half the population."
}

\section{Land Grants}

Among land grant universities, $80 \%$ of librarians are faculty, and $70 \%$ are on tenure track. At $10 \%$, Type 3, "other ranks without tenure," is nearly identical with the entire population, but Type 4, librarians as staff, is found only half as often among land grants as in the entire population.

\section{ARL Libraries}

There are 97 ARL libraries in the population of 119. In this larger population, the proportions of Type 1 and Type 4 are reversed from their position in the land grant population: the largest category is librarians as staff, although the combination of Types 1 and 2 shows that $45 \%$ of the population has librarians who are faculty with tenure, and adding Type 3 to that total shows that more than half of US ARLs have librarians who are faculty.

\section{Public Institutions}

There are 90 public institutions in the population. They include all land grants other than Cornell, all public ARLs that are not land grants, and three non-ARL, non-land grant state universities (University of Montana, University of North Dakota, University of South Dakota). More than $75 \%$ of public institutions in the population have librarians who are faculty, and more than $60 \%$ are on tenure track.

\section{Private Institutions}

There are 29 private universities in the population. They are all large research universities, such as Harvard, Yale, Princeton, Columbia, Cornell, Georgetown, and so on. The difference in the distribution of status types between this segment and others is striking. Only one institution has professorial rank (University of Miami) and only six have librarians who are faculty. Nearly $80 \%$ have librarians who are staff.

\section{Frequencies for the Population}

The basic separation of librarian status into faculty and staff shows that slightly more than three-fifths of the librarians in the population have faculty status for librarians. The details of that status appear in Table 3 and are discussed below.

\section{Institutional Characteristics}

Approximately $80 \%$ of the institutions in the population are members of ARL. Forty-two percent are land grant universities, and $75 \%$ are public institutions. Twenty to thirty percent of the population are located in each of the four census regions, and the population was separated into four groups by size. Forty percent of institutions are their state's "flagship" university.

\section{Librarian Status Characteristics}

\section{Administrator Title}

Forty-eight percent of libraries in the population are headed by a dean, which is a title reserved for academic administrators. "Director" is used in 16\%, while "University Librarian" is found in one quarter of the population. The "other" category includes titles such as "Vice Provost."

\section{Rank System}

The population is divided neatly into three segments that are identical in size, and one that is somewhat smaller. Professorial, Parallel (i.e. Assistant Librarian parallels Assistant Professor), 
Table 3

Summary of Frequencies

\begin{tabular}{lcr}
\hline & Frequency & Percent \\
\hline Institutional characteristics & & \\
ARL & & \\
Yes & 97 & 81.5 \\
No & 22 & 18.5 \\
Total & 119 & 100.0 \\
Land grant & & \\
Yes & 50 & 42.0 \\
No & 69 & 58.0 \\
Total & 119 & 100.0 \\
Public & & \\
Public & 90 & 75.6 \\
Private & 29 & 24.4 \\
Total & 119 & 100.0 \\
Size & & \\
Very large & 30 & 25.2 \\
Large & 30 & 25.2 \\
Medium & 29 & 24.4 \\
Small & 30 & 25.2 \\
Total & 119 & 100.0 \\
Census region & & \\
Northeast & 27 \\
Midwest & 29.7 \\
South & 29 & 24.4 \\
West & 37 & 31.1 \\
Total & 26 & 100.0 \\
& &
\end{tabular}

Librarian status characteristics

Administrator

Dean 57

Director 19

University Librarian 30

Other 13

Total 119

Rank system

Professorial 33

Parallel 33

Librarian 33

Other or undetermined 20

Total 119

Tenure

Yes 61

61

58

16.0

25.2

10.9

100.0

27.7

27.7

27.7

16.8

100.0

51.3

48.7
Table 3 (continued)

Frequency

Percent

Librarian status characteristics

Tenure

Total

100.0

ARL

Senate

Yes

67.2

No

32.8

Total

100.0

Group

Faculty

62.2

Staff

37.8

Total

100.0

Type

1: Professorial

2: Other ranks with tenure

3: Other ranks without tenure

4: Non-faculty (staff)

37.8

and Librarian ranks each represent nearly $28 \%$ of the population, while "other or undetermined" represents the remaining $17 \%$.

Tenure Eligibility

Slightly more than half the librarians in the population are on tenure track. That number includes faculty only. Librarians at a number of institutions, e.g., the University of California system, are staff who have a form of continuing appointment, but those institutions are not included here among those where librarians have tenure.

Faculty Senate Representation

Librarians are represented on the faculty senate in nearly $70 \%$ of institutions, including some institutions where librarians are staff.

\section{Cross Tabulations}

\section{Population Characteristics Cross Tabulated with Status Type}

Librarian Status Type/Institution Size

As size increases, the likelihood of librarians being faculty decreases. The occurrence of Type 3 (faculty without tenure) is consistently low across the spectrum of size (Table 4). The Medium and Large size categories are similar, with about twothirds faculty and one-third staff. The size designations are relative. Even the institutions that are deemed "Small" in this population nevertheless belong to Carnegie classification "Research-High" or "Research-Very High."

\section{Librarian Status Type/Census Region}

The faculty status map is an interesting one. In the Northeast, where there are many large private universities, Type 4 


\begin{tabular}{|c|c|c|c|c|c|}
\hline \multicolumn{6}{|c|}{$\begin{array}{c}\text { Table } 4 \\
\begin{array}{c}\text { Cross Tabulation of Librarian Status Type and } \\
\text { Institution Size }\end{array}\end{array}$} \\
\hline \multirow[b]{2}{*}{$\begin{array}{l}\text { Librarian Status Type/ } \\
\text { Institution Size }\end{array}$} & \multicolumn{4}{|c|}{ Size } & \multirow[b]{2}{*}{ Tota } \\
\hline & $\begin{array}{l}\text { Very } \\
\text { Large }\end{array}$ & Large & Medium & Small & \\
\hline \multicolumn{6}{|l|}{ Type } \\
\hline 1: Professorial & 4 & 6 & 8 & 15 & 33 \\
\hline $\begin{array}{l}\text { 2: Other ranks } \\
\text { with tenure }\end{array}$ & 6 & 11 & 6 & 5 & 28 \\
\hline $\begin{array}{l}\text { 3: Other ranks } \\
\text { without tenure }\end{array}$ & 4 & 3 & 3 & 3 & 13 \\
\hline 4: Non-faculty (staff) & 16 & 10 & 12 & 7 & 45 \\
\hline Total & 30 & 30 & 29 & 30 & 119 \\
\hline
\end{tabular}

dominates, and Type 1 is rare (Table 5). The Midwest is almost evenly split between Type 1 and Type 4, with the two categories in between much rarer. The South has the most institutions represented in the population, and the distribution is nearly even. The West has a somewhat even distribution of Types 1, 2, and 4 . Type 3 is typically the smallest category in any cross tabulation or population segment.

\section{Librarian Status Type/Public/Private Institution}

The status types in which librarians are faculty (Types 1-3) are almost unheard of in the private institutions in this population, where nearly $80 \%$ of librarians are staff (Type 4 ). Librarians are faculty with professorial rank (which is nearly always correlated with tenure) in more than one third of public institutions, and are tenure-track faculty more than half the time (Table 6).

\section{Selected Librarian Status Characteristics Cross Tabulated}

\section{Administrator/Senate}

Librarians with a dean are nearly always represented in the faculty senate (Table 7). Those with a director are more evenly divided, while University Librarian is $40 \%$ yes, $60 \%$ no.

\begin{tabular}{lccccc}
\hline \multicolumn{5}{c}{$\begin{array}{c}\text { Table 5 } \\
\text { Cross Tabulation of Librarian Status Type } \\
\text { and Census Region } \\
\text { and }\end{array}$} & \\
\cline { 1 - 4 } $\begin{array}{l}\text { Librarian Status } \\
\text { Type/US Census } \\
\text { Region }\end{array}$ & Northeast & Midwest & South & West & Total \\
\cline { 2 - 5 } $\begin{array}{l}\text { Type } \\
\text { 1: Professorial }\end{array}$ & 3 & 12 & 9 & 9 & 33 \\
$\begin{array}{l}\text { 2: Other ranks } \\
\text { with tenure }\end{array}$ & 6 & 3 & 10 & 9 & 28 \\
$\begin{array}{l}\text { 3: Other ranks } \\
\text { without tenure }\end{array}$ & 3 & 2 & 7 & 1 & 13 \\
$\begin{array}{l}\text { 4: Non-faculty } \\
\text { (staff) }\end{array}$ & 16 & 12 & 10 & 7 & 45 \\
Total & 28 & 29 & 36 & 26 & 119 \\
\hline
\end{tabular}

\section{Table 6 \\ Cross Tabulation of Librarian Status Type and Public/ Private Institution}

\begin{tabular}{lccr}
\hline \multirow{2}{*}{$\begin{array}{l}\text { Librarian Status Type/ } \\
\text { Public/Private }\end{array}$} & \multicolumn{2}{c}{ Public/Private } & \\
\cline { 2 - 3 } & Public & Private & Total \\
\hline Type & 32 & 1 & \\
1: Professorial & 25 & 3 & 28 \\
2: Other ranks with tenure & 11 & 2 & 13 \\
3: Other ranks without tenure & 22 & 23 & 45 \\
4: Non-faculty (staff) & 90 & 29 & 119 \\
Total & & &
\end{tabular}

Administrator/Rank System

"Dean" is the most frequent administrative title in the population. It coincides with professorial ranks in nearly half the institutions whose library has a dean. University Librarian accounts for about $25 \%$ of the population. It occurs in all the University of California Campuses and in many large private universities, as well as in some state universities, including some larger land grants.

\section{Administrator/Tenure}

Dean as administrator has a strong association with librarians who are tenure-track faculty. Director coincides with no tenure (Type 3 or 4) more than three-to-one, while University Librarian coincides with no tenure twice as often as tenure track.

\section{Rank System/Senate}

Professorial ranks are an excellent predictor of senate representation, while librarian ranks are split about 50-50.

\section{Tenure/Senate}

Librarians who have tenure are represented in the senate. The 60 institutions without tenure either have staff librarians or nontenured faculty. Forty of those institutions have no senate representation for librarians.

\section{Tenure/Rank System}

Professorial rank nearly always correlates with tenure. Parallel ranks are split more equally, while librarian ranks are least likely to correlate with tenure.

\section{Discussion of Findings and Conclusion}

The 1999 ACRL survey on faculty status among academic librarians ${ }^{29}$ assesses the implementation of ACRL's nine conditions for librarian faculty status and provides a basis for comparison, although it does not explicitly discuss whether librarians in the institutions surveyed are faculty or staff. The survey's category of doctoral-granting universities $(n=271)$ includes all US universities in the present population. Forty-six percent of doctoral-granting institutions in the ACRL survey have librarians who are on tenure track, $53 \%$ have collegial governance, and $45.6 \%$ have peer review for promotion. Considered together, those three things might be taken as an indication of faculty status. "Tenure" is a condition that is exclusive to faculty, although this data element may include 
Table 7

Summary of Cross Tabulation of Librarian Status Characteristics

\begin{tabular}{|c|c|c|c|c|c|}
\hline \multirow[b]{2}{*}{ Administrator/Senate } & \multicolumn{2}{|c|}{ Senate } & \multirow[b]{2}{*}{ Total } & & \\
\hline & Yes & No & & & \\
\hline \multicolumn{6}{|l|}{ Administrator } \\
\hline Dean & 50 & 7 & 57 & & \\
\hline Director & 11 & 8 & 19 & & \\
\hline University librarian & 12 & 18 & 30 & & \\
\hline Other & 7 & 6 & 13 & & \\
\hline \multirow[t]{2}{*}{ Total } & 80 & 39 & 119 & & \\
\hline & \multicolumn{4}{|c|}{ Rank system } & \\
\hline Administrator/Rank System & Professorial & Parallel & Librarian & Other/undet. & Total \\
\hline \multicolumn{6}{|l|}{ Administrator } \\
\hline Dean & 26 & 15 & 13 & 3 & 57 \\
\hline Director & 2 & 6 & 8 & 3 & 19 \\
\hline University librarian & 5 & 8 & 7 & 10 & 30 \\
\hline Other & 0 & 4 & 5 & 4 & 13 \\
\hline Total & 33 & 33 & 33 & 20 & 119 \\
\hline
\end{tabular}

Tenure

Administrator/Tenure

\begin{tabular}{lll}
\multicolumn{2}{c}{ Tenure } & \\
Yes & No & Total
\end{tabular}

Administrator

Dean

Director

$44 \quad 13 \quad 57$

University librarian

$\begin{array}{lll}4 & 15 & 19\end{array}$

Other

10

20

30

$3 \quad 10 \quad 13$

Total

61

58

119

Senate

Rank System/Senate

\begin{tabular}{lrr}
\multicolumn{3}{c}{ Senate } \\
\hline Yes & No & Tota
\end{tabular}

Rank system

Professorial

Yes

Total

Parallel

33

33

Librarian

27

33

Other or undetermined

17

33

Total

3


Table 7 (continued)

\begin{tabular}{lrrr}
\hline & \multicolumn{2}{c}{ Senate } & \\
\cline { 2 - 4 } Tenure/Senate & Yes & No & Total \\
\hline Tenure & 60 & 0 & 60 \\
Yes & 20 & 39 & 59 \\
No & 80 & 39 & 119 \\
Total & & & \\
\cline { 2 - 4 } & Yes & Tenure & \\
Tenure/Rank System & & 3 & 33 \\
\hline Rank system & 30 & 14 & 33 \\
Professorial & 19 & 24 & 33 \\
Parallel & 9 & 20 & 20 \\
Librarian & 0 & 58 & 119 \\
Other or undetermined & 58 & 3 & \\
Total & & & \\
\hline
\end{tabular}

continuing appointment systems of some librarians who are academic staff. In any case, if an estimated $45 \%$ to $50 \%$ of librarians at all the doctoral-granting universities surveyed by ACRL are tenure-track faculty, that number is close to the approximately $51 \%$ who have that status in the present population of US research universities.

The typology that was created based on land grant universities is still useful in this expanded population. It reveals the basic divisions of faculty and staff and the salient characteristics of rank and tenure. The typology allows comparison of institutional characteristics such as size, segments of the population such as private or public universities, and cross tabulation of other librarian status characteristics such as administrator title or senate representation. It has proven both valid and reliable: as a way of organizing information about librarian status, and as a way of comparing institutions and population segments.

\section{"The distribution of types among land grants showed that $80 \%$ of librarians are faculty, and $\mathbf{7 0} \%$ on tenure track, leaving $20 \%$ as staff."}

Extending the typology to a larger population is revealing. The distribution of types among land grants showed that $80 \%$ of librarians are faculty, and $70 \%$ on tenure track, leaving $20 \%$ as staff. In the expanded population of US research libraries, the proportions are $62 \%$ faculty, $51 \%$ tenure track, and $37 \%$ staff, i.e., the rate of librarians as staff is nearly doubled in the larger population. When only the public institutions in the population are considered, however, $76 \%$ of librarians are faculty, and $64 \%$ on tenure track. Conversely, among private institutions, the proportions are reversed: $80 \%$ of librarians are staff, and only $13 \%$ are tenure-track faculty. Among all segments of the population except private universities, Type 3, faculty who are not on tenure track, is the least common type.

The status of librarians can be viewed through several of the aspects of prototype theory. While they are not central or prototypical members of the "faculty" category, it can be argued that there is a family resemblance among teaching faculty and librarians, that in some institutions faculty status is a graded category, with librarians having a lesser degree of membership (with their status qualified by an adjective such as "special"), and that a prototypical teaching faculty member is the generator for the category, with librarian membership generated by the application of rules. It can also be argued that the true category is actually something broader, such as "academic" or "academic staff/professional" and that librarians and "faculty" or "teaching faculty" are both members of that category, along with other groups.

The results of applying the status typology to this population raise many more questions. Two obvious areas for further research are to look more closely at particular segments of the population and to examine each status type more closely as well. The differences in status types between public and private universities are very interesting, as is the geographic distribution of types. Type 4, in which librarians are not faculty but staff, needs further investigation. A closer examination of Type 4 libraries might yield another typology that reflects the variations in academic staff status. Being designated "faculty" is not a predictor of the details of that status, and the same is true of being designated "staff."

Another way of looking more closely at the typology categories is to analyze the semantics of the types and their components. "Faculty," "staff," "tenure," "dean," and so on, have particular and significant meanings in higher education. 
Linguistic typology and prototype semantics have been touched on here, but further linguistic analysis using those and other concepts and techniques could shed more light on librarian status.

\section{Appendix A. Supplementary Data}

Supplementary data associated with this article can be found, in the online version, at doi:10.1016/j.acalib.2008.06.005.

\section{Notes AND REFERENCES}

1. American Library Association, Joint Statement on Faculty Status of College and University Librarians. http://www.ala.org/ala/acrl/ acrlstandards/jointstatementfaculty.htm. (accessed October 15, 2007)

2. Association of College and Research Libraries, "ACRL model statement of criteria and procedures for appointment, promotion in academic rank, and tenure for college and university librarians," College \& Research Libraries News (September/October 1973): 192-95, 243-247.

3. Association of College and Research Libraries, "ACRL standards for faculty status for college and university librarians," College \& Research Libraries News (May 1974): 112-113.

4. Association of College and Research Libraries, ACRL Statement on the Terminal Professional Degree for Academic Librarians. Chicago: American Library Association/Association of College and Research Libraries, 1975.

5. American Library Association, Standards for Faculty Status for College and University Librarians, September 06, 2006. http:// www.ala.org/ala/acrl/acrlstandards/standardsfaculty.cfm (accessed October 15, 2007)

6. University of Montana, University of North Dakota, and University of South Dakota are not large enough to qualify as members of ARL, and those three states have land grant institutions that are separate from the "flagship" institution.

7. Carnegie Classification of Institutions of Higher Education. Available: http://www.carnegiefoundation.org/classifications/index.asp.

8. Mary K. Bolin, "A Typology of Librarian Status at Land Grant Universities," Journal of Academic Librarianship 34, no. 3 (05, 2008): 220-230.

9. Bernard Comrie, Language Universals and Linguistic Typology. Oxford: Blackwell, 1989. 2nd ed.

10. William Croft, Typology and Universals. Cambridge: Cambridge UP, 1990.

11. Joseph Greenberg, Language Universals: with Special Reference to Feature Hierarchies. Berlin: Mouton, 2005.

12. Eleanor Rosch, Basic Objects in Natural Categories. Berkeley: University of California Language Behavior Research Laboratory, 1975;

Eleanor Rosch, "Human categorization," Studies in Cross-Cultural Psychology, (Vol. 1). London: Academic Press, 1977;
E.H. Rosch, "Natural categories," Cognitive Psychology 4 (1973): 328-350.

13. George Lakoff, Women, Fire, and Dangerous Things: What Categories Reveal about the Mind. Chicago: University of Chicago, 1987;

George Lakoff \& Mark Johnson, Metaphors We Live By. Chicago: University of Chicago Press, 1980.

14. Mary K. Bolin, "A Typology of Librarian Status at Land Grant Universities."

15. Tracy Bicknell-Holmes and Kay Logan-Peters, External Review for Promotion and Tenure. SPEC kit No. 293, Washington, DC: Association of Research Libraries, 2006.

16. Susan A. Massey and Mary Ann Sheble, Faculty Organizations in ARL Libraries: Activities and Documents. SPEC Kit. Vol. 206 Washington, DC: Association of Research Libraries, Office of Management Services, 1995.

17. Jack Siggins and Ronald P. Naylor, Academic Status for Librarians in ARL Libraries/Systems and Procedures Exchange Center. Washington, DC: Association of Research Libraries, Office of Management Services, 1992.

18. Virgil F. Massman, Faculty Status for Librarians (Metuchen, N.J.: Scarecrow Press, 1972.

19. W. Bede Mitchell, Faculty Status for Academic Librarians: Compliance with Standards, Opinions of University Administrators, and a Comparison of Tenure-Success Records of Librarians and Instructional Faculty. ( $\mathrm{PhD}$ diss., Montana State University, 1990).

20. W. Bede Mitchell and Mary Reichel, "Publish or perish: A Dilemma for Academic Librarians?," College \& Research Libraries 60, no. 3 (05, 1999): 232.

21. Shannon Cary, "Faculty Rank, Status, and Tenure for Librarians," College \& Research Libraries News 62 no. 5 (05, 2001): 510.

22. Association of College and Research Libraries, "Faculty Rank, Status, and Tenure for Librarians," In 1999 Academic Library Trends \& Statistics (Chicago: ACRL, 2000).

23. Janet Krompart and ClaraDiFelice, "A Review of Faculty Status Surveys, 1971-1984," Journal of Academic Librarianship 13, no. $1(03,1987): 17$.

24. Lakoff 1987 , p. 12.

25. Association of Research Libraries, "Member Libraries." Available: http://www.arl.org/arl/membership/members.shtml (February 4, 2008).

26. “ARL Stats at UVa Library: Ranked Lists.” Available: http://fisher. lib.virginia.edu/cgi-local/arlbin/arl.cgi?task=setuprank (February 4, 2008)

27. "Land Grant Institutions," Available: http://www.higher-ed.org/ resources/land_grant_colleges.htm (February 4, 2008).

28. Census Bureau Region and Division Codes and State and County Federal Information Processing System (FIPS) Codes. Available: http://www.census.gov/popest/geographic/codes02.html (February 4, 2008).

29. ACRL, "Faculty Rank, Status, and Tenure for Libarians." 